\title{
Crystal structure of hexabarium mononitride pentaindide, $\left(\mathrm{Ba}_{6} \mathbf{N}\right)\left[\mathbf{I n}_{5}\right]$
}

\author{
A. Schlechte, Yu. Prots and R. Niewa* \\ Max-Planck-Institut für Chemische Physik fester Stoffe. Nöthnitzer Str. 40, 01187 Dresden, Germany
}

Received October 1. 2004, accepted and available on-line November 12, 2004; CSD no. 409805

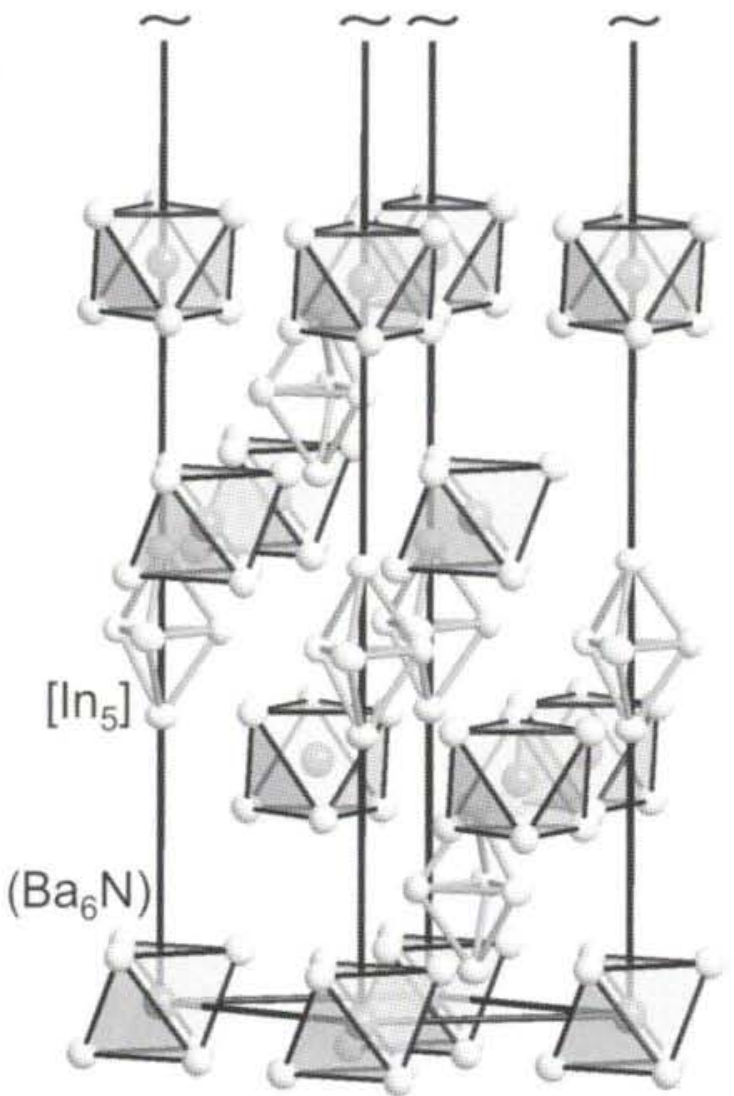

Abstract

Ba 6 InsN, trigonal, $R \overline{3} c$ (no. 167), $a=8.234(3) \AA$, $c=44.12(2) \AA, V=2590.6 \AA^{3}, Z=6, R_{\mathrm{gt}}(F)=0.028$, $w R_{\text {ref }}\left(F^{2}\right)=0.060, T=293 \mathrm{~K}$.

\section{Source of material}

Single crystals of $\left(\mathrm{Ba}_{6} \mathrm{~N}\right)$ [Ins] with metallic lustre were obtained from reaction of melt beads of the general composition 'Ba3In' with nitrogen atmosphere at $973 \mathrm{~K}$ next to further ternary phases. Nearly single phase material (according to X-ray powder diffraction) was obtained under the same conditions starting from melt beads with the bulk composition 'Ba6In ${ }_{5}$ ' after two reannealing cycles at $973 \mathrm{~K}$.

\section{Experimental details}

Chemical analyses on impurities of $\mathrm{H}$ and $\mathrm{O}$ were carried out using the carrier gas hot-extraction technique on a LECO analyzer TCH-600. Lattice parameters were obtained from leastsquares fittings of reflections taken from a Guinier powder pattern (Cu $K_{\alpha 1}$ radiation, $\lambda=1.540598 \AA$ ).

\footnotetext{
* Correspondence author (e-mail: niewa@cpfs.mpg.de)
}

\section{Discussion}

Indium, when combined with alkaline-earth elements forms a variety of ternary nitrides. The compounds known so far may be described as built from indium clusters and octahedra of alkalineearth cations surrounding nitride ions. In the latter cationic substructure the polyhedra might be isolated, vertex-, and/or edgesharing. The variety of In arrangements extends from isolated In species in $\left(\mathrm{Ca}_{7} \mathrm{~N}_{4}\right) \mathrm{In}_{1.04}$ [1], isolated tetrahedral units in $\left(A_{19} \mathrm{~N}_{7}\right)\left[\operatorname{In}_{4}\right]_{2}(A=\mathrm{Ca}, \mathrm{Sr}, \mathrm{Ba})[2,3]$, trigonal bipyramidal [Ins] clusters next to $\left[\mathrm{In}_{8}\right]$ ions of more complicated geometry in $\left(\mathrm{Ba}_{38} \mathrm{~N}_{18}\right)$ [Ins $]_{2}\left[\mathrm{In}_{8}\right]$ [4], and infinite chains in $\left(A_{4} \mathrm{~N}\right)\left[\mathrm{In}_{2}\right](A=$ $\mathrm{Ca}, \mathrm{Sr})[5]$ and $\left(\mathrm{Ca}_{2} \mathrm{~N}\right)$ In [6]. None of these metallic compounds follows Zintl-like counting. The new compound $\left(\mathrm{Ba}_{6} \mathrm{~N}\right)$ [In 5$]$ is an isotype of $\left(A_{6} \mathrm{~N}\right)[\mathrm{Gas}](A=\mathrm{Sr}, \mathrm{Ba})$ [7].

The crystal structure of $\left(\mathrm{Ba}_{6} \mathrm{~N}\right)$ [Ins] is characterized as rocksalt type motif of $\mathrm{N}$-centred octahedra $\left(\mathrm{Ba}_{6} \mathrm{~N}\right)$ and trigonal bipyramidal clusters [Ins]. The trigonal bipyramidal units [Ins] might be described as [Ins] ${ }^{7-}$ ions, quite the same according to Zintl-type electronic counting and using the Wade-rules for closo-cluster. The isotypes $\left(A_{6} \mathrm{~N}\right)[\mathrm{Gas}]$ were previously described by the formula $\left(A^{2+}\right)_{6}\left(\mathrm{~N}^{3-}\right)[\mathrm{Gas}]^{7-} \cdot 2 \mathrm{e}^{-}$based on electronic structure calculations. An alternate speculation on unnoticed hydride ion impurities in the sense of ' $\left(A_{6} \mathrm{~N}\right)\left[E_{5}\right] \mathrm{H}_{2}{ }^{\prime}$ ( $E=\mathrm{Ga}$, In) is falsificated for the title compound by chemical analyses on hydrogen on a nearly single phase sample: The hydrogen content is below the detection limit of $160 \mathrm{ppm}$ ('(Bar N) [Ins] $\mathrm{H}_{2}$ : : $\left.1400 \mathrm{ppm}\right), w(\mathrm{O})=0.10(3) w t . \%$. For the [Ins] cluster in $\left(\mathrm{Ba}_{38} \mathrm{~N}_{18}\right)\left[\mathrm{In}_{5}\right]_{2}\left[\mathrm{In}_{8}\right]$ a highly electron deficient situation $\left(\left[\mathrm{In}_{5}\right]^{5-}\right)$ was derived [4]. Distances within the [Ins] unit in $\left(\mathrm{Ba}_{6} \mathrm{~N}\right)$ [Ins] with $d(\mathrm{In}-\mathrm{In})_{\text {equatorial }}=3.061(1) \AA$ and $d(\mathrm{In}-\mathrm{In})_{\text {ax }}$ ial $=3.057(1) \AA$ are in the range of the respective distances in $\left(\mathrm{Ba}_{38} \mathrm{~N}_{18}\right)\left[\mathrm{In}_{5}\right]_{2}\left[\mathrm{In}_{8}\right]$ with $d(\mathrm{In}-\mathrm{In})_{\text {equatorial }}=3.115(1) \AA$, $3.164(1) \AA$ and $d(\mathrm{In}-\mathrm{In})_{\text {axial }}=2.955(1) \AA-3.224(2) \AA$. The distances in the isolated $\left(\mathrm{Ba}_{6} \mathrm{~N}\right)$ octahedra with $d(\mathrm{Ba}-\mathrm{N})=$ 2.7827(8) $\AA$ are similar to those in $\left(\mathrm{Ba}_{6} \mathrm{~N}\right)[\mathrm{Gas}](d(\mathrm{Ba}-\mathrm{N})=$ 2.734(1) $\AA$ ).

Table 1. Data collection and handling.

\begin{tabular}{ll}
\hline Crystal: & gray platelet, \\
& size $0.035 \times 0.110 \times 0.110 \mathrm{~mm}$ \\
Wavelength: & Mo $K_{\alpha}$ radiation $(0.71073 \AA)$ \\
$\mu$ : & $199.35 \mathrm{~cm}^{-1}$ \\
Diffractometer, scan mode: & Rigaku AFC 7 Mercury CCD, \\
& $\chi=0^{\circ}, \omega=0^{\circ}, 2 \theta=-10^{\circ}, \varphi=0^{\circ}-180^{\circ}$, \\
& $\Delta \varphi=0.5^{\circ}, t=6 \mathrm{sec}$ \\
& $\chi=-90^{\circ}, \varphi=25^{\circ}, 2 \theta=-10^{\circ}, \omega=0^{\circ}-60^{\circ}$, \\
& $\Delta \omega=0.5^{\circ}, t=6 \mathrm{sec}$ \\
$2 \theta_{\text {max }}:$ & $67.1^{\circ}$ \\
$N(h k l)_{\text {measured, }} N(h k l)_{\text {)nique: }}:$ & 8837,1079 \\
Criterion for $I_{\text {obs, }} N(h k l)_{\text {gt }}:$ & $I_{\text {obs }}>2 \sigma\left(I_{\text {obs }}\right), 1021$ \\
$N(\text { param })_{\text {hefined: }}$ & 20 \\
Programs: & SHELXS-97 [8], SHELXL-97 [9]
\end{tabular}


Table 2. Atomic coordinates and displacement parameters (in $\AA^{2}$ ).

\begin{tabular}{lllllllllll}
\hline Atom & Site & $x$ & $y$ & $z$ & $U_{11}$ & $U_{22}$ & $U_{33}$ & $U_{12}$ & $U_{13}$ & $U_{23}$ \\
\hline $\mathrm{Ba}(1)$ & $36 c$ & $0.10028(4)$ & $0.31724(4)$ & $0.035077(6)$ & $0.0171(1)$ & $0.0199(1)$ & $0.0195(1)$ & $0.0095(1)$ & $-0.00062(8)$ & $-0.00081(9)$ \\
$\operatorname{In}(1)$ & $18 e$ & $0.21465(5)$ & 0 & $1 / 4$ & $0.0162(1)$ & $0.0248(2)$ & $0.0192(2)$ & $1 / 2 U_{22}$ & $-0.00083(8)$ & $2 U_{13}$ \\
$\operatorname{In}(2)$ & $12 c$ & 0 & 0 & $0.19348(1)$ & $0.0213(2)$ & $U_{11}$ & $0.0153(2)$ & $1 / 2 U_{11}$ & 0 & 0 \\
$\mathrm{~N}(1)$ & $6 b$ & 0 & 0 & 0 & $0.023(3)$ & $U_{11}$ & $0.025(5)$ & $1 / 2 U_{11}$ & 0 & 0 \\
\hline
\end{tabular}

Acknowledgments. We thank Ulrike Schmidt for performing the chemical analyses and Prof. Dr. Rüldiger Kniep for fruitful discussions.

\section{References}

1. Höhn, P.; Ramlau, R.; Rosner, H.; Schnelle, W.; Kniep, R.: $\left(C_{a 7} N_{4}\right) M_{x}$ $(M=\mathrm{Ag}, \mathrm{Ga}, \mathrm{In}, \mathrm{Tl})$ : Subnitride und Metallketten ${ }_{\infty}^{1} M_{x}$. Z. Anorg. Allg. Chem. 630 (2004) 1704

2. Cordier, G.; Rönninger, S.: Zur Strukturchemie von Erdalkali-NitridoGallaten und -Indaten. Z. Kristallogr. Suppl. 182 (1988) 60-61.

3. Kirchner, M.; Wagner, F. R.; Schnelle, W.; Niewa, R.: Beiträge zur Verbindungsbildung im System Ca-In-N. Z. Anorg. Allg. Chem. 630 (2004) 1735.

4. Yamane, H.; Sasaki, S.; Kajiwara, T.; Yamada, T.; Shimada, M.: Ba 19 IngNg, a subnitride containing isolated $\left[\mathrm{In}_{5}\right]^{5-}$ and $\left[\mathrm{In}_{8}\right]^{12-} \mathrm{Zintl}$ anions. Acta Crystallogr. E60 (2004) il20-il23.

5. Cordier, G.; Rönninger, S.: Darstellung und Kristallstruktur von Ca4ln $2 \mathrm{~N}$ und SraIn 2 N. Z. Naturforsch. $42 b$ (1987) 825-827.

6. Bailey, M. S.; DiSalvo, F. J.: The synthesis and structure of $\mathrm{Ca}_{2} \operatorname{InN}$, a novel ternary indium nitride. J. Alloys Compd. 353 (2003) 146-152.

7. Cordier, G.; Ludwig, M.; Stahl, D.; Schmidh, P. C.; Kniep, R.: (SI 6 N)[Gas] and $\left(\mathrm{Ba}_{6} \mathrm{~N}\right)$ [Gas]: Compounds with Discrete $\left(M_{6} \mathrm{~N}\right)$ Octahedra and [Gas] Clusters. Angew. Chem. Int. Ed. 34 (1995) 1761-1763.

8. Sheldrick, G. M.: SHEL XS-97. Program for the Solution of Crystal Structures. University of Göttingen, Germany 1997.

9. Sheldrick, G. M.: SHELXI_97. Program for the Refinement of Crystal Structures. University of Göttingen, Germany 1997. 